\title{
WIOLETTA JEDLECKA
}

Uniwersytet Wrocławski

\section{PODSTAWOWE FORMY PRAWNE DZIAŁANIA ADMINISTRACJI PUBLICZNEJ NA RZECZ OCHRONY ZWIERZĄT}

\section{WPROWADZENIE}

Prawna ochrona zwierząt stanowi materię bardzo zróżnicowaną, obecną w wielu gałęziach prawa. W sposób najbardziej wszechstronny problematyka ta jest uwzględniona $\mathrm{w}$ regulacjach z zakresu prawa administracyjnego, a uzasadnione to jest specyfiką przedmiotu ochrony. Odpowiednie traktowanie zwierząt i zapewnienie im bezpiecznej oraz należytej egzystencji utożsamiane jest z interesem publicznym, którego realizację i ochronę najlepiej gwarantować mogą właśnie normy prawa publicznego, w szczególności zaś prawa administracyjnego. Celem niniejszego tekstu jest wskazanie, za pomocą jakich unormowań prawa administracyjnego można określić system nakazów i zakazów w zakresie postępowania ze zwierzętami, zadania organów władzy publicznej, a także obowiązki innych podmiotów w tej dziedzinie oraz instrumenty zapewniające egzekwowanie tych praw, ponadto zasady prowadzenia danej działalności z użyciem różnych kategorii i grup zwierząt ${ }^{1}$.

\section{FORMY DZIAŁANIA ADMINISTRACJI NA RZECZ OCHRONY ZWIERZĄT}

Problematyka odnosząca się do prawnej ochrony zwierząt, będąca ważną częścią materialnego prawa administracyjnego, uregulowana jest $\mathrm{w}$ wielu ustawach. Wymienić w tym miejscu należy zwłaszcza:

1) Ustawę $z$ dnia 21 sierpnia 1997 r. o ochronie zwierząt ${ }^{2}$;

2) Ustawę z dnia 13 października 1995 r. - Prawo łowieckie³;

${ }^{1}$ M. Goettel, Sytuacja zwierzęcia w prawie cywilnym, Warszawa 2013, s. 234.

2 Tekst jedn.: Dz.U. 2013, poz. 856.

3 Tekst jedn.: Dz.U. 2015, poz. 2168. 
3) Ustawę z dnia 16 kwietnia 2004 r. o ochronie przyrody4;

4) Ustawę z dnia 29 czerwca 2007 r. o organizacji hodowli i rozrodzie zwierząt gospodarskich ${ }^{5}$;

5) Ustawę z dnia 22 czerwca 2001 r. o organizmach genetycznie zmodyfikowanych ${ }^{6}$;

6) Ustawę z dnia 27 kwietnia 2001 r. — Prawo ochrony środowiska ${ }^{7}$;

7) Ustawę z dnia 29 stycznia 2004 r. o Inspekcji Weterynaryjnej8;

8) Ustawę z dnia 11 marca 2004 r. o ochronie zdrowia zwierząt oraz o zwalczaniu chorób zakaźnych zwierząt ${ }^{9}$;

9) Ustawę z dnia 18 grudnia 2003 r. o zakładach leczniczych dla zwierząt ${ }^{10}$;

10) Ustawę $z$ dnia13 kwietnia 2007 r. o zapobieganiu szkodom w środowisku i ich naprawie ${ }^{11}$;

11) Ustawę z dnia 19 grudnia 2014 r. o rybołówstwie morskim ${ }^{12}$;

12) Ustawę z dnia 18 kwietnia 1985 r. o rybactwie śródlądowym ${ }^{13}$;

13) Ustawę z dnia 15 stycznia 2015 r. o ochronie zwierząt wykorzystywanych do celów naukowych lub edukacyjnych ${ }^{14}$.

Podkreślić należy fakt, że w toku prac legislacyjnych nad przebudową prawa ochrony środowiska w Polsce część doktryny opowiadała się za wyodrębnieniem wszystkich zagadnień związanych z prawnoadministracyjną ochroną zwierząt w odrębny kodeks prawa ochrony zwierząt. Na razie kodeks taki jednak jeszcze nie powstał ${ }^{15}$.

Oprócz ustawowej reglamentacji, głównie w drodze ustanowienia systemu nakazów i zakazów, określonych dziedzin stosunków społecznych związanych ze zwierzętami, w ramach której ma także miejsce regulowanie określonych kwestii szczegółowych w drodze przepisów wykonawczych naczelnych organów administracji państwowej albo aktów prawa miejscowego (oczywiście w trybie upoważnień), prawo administracyjne przewiduje rozstrzyganie indywidualnych przypadków mocą decyzji administracyjnych. Rzadziej korzysta się z innych prawnych

\footnotetext{
4 Tekst jedn.: Dz.U. 2013, poz. 627.

5 Dz.U. 2007 Nr 133, poz. 921.

6 Tekst jedn.: Dz.U. 2007 Nr 36, poz. 233 ze zm.

7 Tekst jedn.: Dz.U. 2013, poz. 1232.

8 Tekst jedn.: Dz.U. 2015, poz. 1482.

9 Tekst jedn.: Dz.U. 2014, poz. 29.

10 Tekst jedn.: 2015, poz. 1047.

11 Dz.U. 2007 Nr 75, poz. 493 ze zm.

12 Dz.U. 2015, poz. 222.

13 Tekst jedn.: Dz.U. 2015, poz. 652.

14 Dz.U. 2015, poz. 266.

15 J. Stelmasiak, Administracyjnoprawne aspekty ochrony zwierzat, [w:] Prawna ochrona zwierząt, red. M. Mozgawa, Lublin 2002, s. 155.
} 
form działania administracji publicznej, jak czynności materialno-techniczne, działalność społeczno-organizatorska czy umowy cywilnoprawne ${ }^{16}$.

Rozważając zagadnienia administracyjnoprawnych środków ochrony zwierząt, nie sposób pominąc kwestii odpowiedzialności administracyjnej w ochronie środowiska ${ }^{17}$. Odpowiedzialność może być charakteryzowana jako ocena postawy i zachowania człowieka, ale też jako składnik funkcjonowania kontroli społecznej. Stanowi ona zasadę ponoszenia przez podmiot ujemnych konsekwencji przewidzianych prawem, powstałych ze względu na stany rzeczy lub zdarzenia podlegające ujemnej kwalifikacji normatywnej i przypisane podmiotowi w obowiązującym porządku prawnym ${ }^{18}$. Kamila Kwaśnicka wskazuje, że sanacyjna odpowiedzialność administracyjna jest ponoszeniem przez administrowanych sankcji przewidzianych prawem, wymierzanych w procedurze swoistej dla administracji, za działania lub zaniechania oraz zdarzenia, które podlegają ujemnej kwalifikacji normatywnej ${ }^{19}$. Ze względu na znaczenie środowiska w życiu człowieka można stwierdzić, że bez względu na formę i zasięg skutków szkodzenie środowisku jest, bądź też może być, oceniane negatywnie. Powstaje jednak w tym miejscu pytanie, czy ta ocena zawsze ma możliwość pociągania za sobą regulowanego prawem zadośćuczynienia. Jeśli porządek prawny przewiduje odpowiedzialność, a stan środowiska ulega pogorszeniu, oznacza to, że proces egzekwowania jest osłabiony lub nie ma go w ogóle, ale też, że rozmiar odpowiedzialności jest nieadekwatny do potrzeb. Rozgraniczając odpowiedzialność administracyjną od innych rodzajów odpowiedzialności, należy mieć na uwadze w szczególności:

— cel tej odpowiedzialności;

— jej podstawę w prawie administracyjnym;

- rolę organów administracji oraz

— jej realizację przy zastosowaniu instytucji postępowania administracyjnego.

Odpowiedzialność administracyjnoprawną w zakresie ochrony środowiska rozumie się jako „regulowaną prawem możliwość uruchomienia wobec określonego podmiotu, z powodu jego działalności naruszającej stan środowiska, środków prawnych realizowanych w swoistych dla administracji formach i procedurze" 20 . Aleksander Lipiński definiuje odpowiedzialność administracyjną w kontekście ochrony środowiska jako zbiór nakazów i zakazów określonego zachowania się ustalony przez organ administracji publicznej. Owe nakazy i zakazy dotyczą w szczególności:

— cofnięcia lub ograniczenia zakresu decyzji zezwalającej na dany sposób korzystania ze środowiska i jego zasobów;

16 M. Goettel, op. cit., s. 234.

17 J. Stelmasiak, op. cit., s. 155.

18 J. Ciechanowicz-McLean, Polskie prawo ochrony przyrody, Warszawa 2006, s. 169.

19 K. Kwaśnicka, Odpowiedzialność administracyjna w prawie ochrony środowiska, Warszawa 2011, s. 66.

20 J. Boć, K. Nowacki, E. Samborska-Boć, Ochrona środowiska, Wrocław 2000, s. 321-325. 
- wstrzymania działalności;

- stosowania odpowiednich urządzeń ochronnych, usunięcia uchybień bądź ich szkodliwych następstw.

Stosowanie wskazanych rozwiązań często pozwala osiągnąć skutek podobny do tego, jaki można osiągnąć na drodze cywilnoprawnej, jednakże metody i funkcje tych rodzajów odpowiedzialności są zupełnie różne, a decydującym kryterium jest zwłaszcza nadrzędność organu administracyjnego nad stroną oraz równorzędność stron w stosunku cywilnoprawnym. Instrumenty administracyjnoprawne mają zdecydowanie na celu ochronę interesu publicznego przy wykorzystaniu możliwości władczego oddziaływania na sferę podmiotu prawa. Formą działania organu administracji publicznej jest m.in. sprawowanie nadzoru oznaczającego ustaloną prawem kompetencję do badania postępowania strony pod kątem zgodności z określonym przez prawo wzorcem oraz orzekania w zakresie konsekwencji stwierdzonych uchybień. Działania zmierzające do usunięcia stanu niezgodnego z prawem podlegają ustaleniu w drodze administracyjnej. Dla zagadnień regulowanych przepisami związanymi z ochroną środowiska najbardziej znaczące są decyzje naprawcze, interwencyjne, wstrzymujące działalność oraz nakładające sankcję finansową ${ }^{21}$. Odpowiedzialność administracyjna obejmuje jedynie konsekwencje naruszeń sformułowane normatywnie. Zawsze podlega jej konkretnie określony podmiot. Działalnością naruszającą jest działalność szkodząca, nawet jeśli byłaby ona dopuszczona prawnie ${ }^{22}$. W prawie ochrony środowiska stosuje się różne regulacje, z przewagą metod regulacji właściwej prawu administracyjnemu, często o charakterze władczym. Istnieje więc silny związek prawa ochrony środowiska z prawem administracyjnym, a odpowiedzialność i sankcja administracyjna w tej dziedzinie prawa mają istotne znaczenie. W rozumieniu rekomendacji przyjętej przez Komitet Ministrów Rady Europy nr R (91) 1 z 13 lutego 1991 r. w sprawie sankcji administracyjnych konstytutywnymi cechami tej sankcji są: ustalenie dolegliwości z zamiarem ukarania podmiotu i zastosowanie określonego środka poprzez podjęcie aktu administracyjnego. Komitet zlecił przy tym państwom członkowskim UE uwzględnienie pewnych zasad w swoim prawie wewnętrznym. I tak, zasady te stanowią, że:

— nie wolno nałożyć sankcji, jeśli czyn nie podlegał karze w czasie jego popełnienia;

— sankcje oraz warunki, w jakich mogą one być nakładane, powinny zostać określone na drodze ustawowej;

- istnieje zakaz dwukrotnego karania administracyjnego za ten sam czyn i na mocy tego samego przepisu bądź przepisów, które chronią ten sam interes społeczny;

21 A. Lipiński, Prawne podstawy ochrony środowiska, Kraków 2005, s. 415-416.

22 Ibidem, s. 417-422. 
— postępowanie wszczęte w sprawie nałożenia sankcji musi być zakończone rozstrzygnięciem;

— działania zmierzające do uruchomienia sankcji powinny zostać podjęte w rozsądnym terminie.

Jako przykład sankcji administracyjnej można wskazać art. 7 ust. 1 ustawy — Prawo ochrony środowiska, w którym to przewidziano możliwość czasowego odebrania zwierzęcia właścicielowi lub opiekunowi na podstawie decyzji wójta (burmistrza, prezydenta miasta) właściwego ze względu na miejsce pobytu zwierzęcia i przekazania go: 1) schronisku dla zwierząt, jeśli jest to zwierzę domowe lub laboratoryjne, lub 2) gospodarstwu rolnemu wskazanemu przez wójta (burmistrza, prezydenta miasta), jeśli jest to zwierzę gospodarskie, lub 3) ogrodowi zoologicznemu lub schronisku dla zwierząt, jeśli jest to zwierzę wykorzystywane do celów rozrywkowych, widowiskowych, filmowych, sportowych lub utrzymywane w ogrodach zoologicznych. Brak odrębnych regulacji w zakresie wymierzania sankcji administracyjnych wiąże się z tym, że przepisy procesowe związane z ich wymierzaniem znajdują się $\mathrm{w}$ aktach prawnych regulujących określone kategorie spraw, a nie tylko w k.p.a. sankcja jest związana z dolegliwością dla podmiotu, wobec którego została wymierzona ${ }^{23}$.

Zdaniem Jerzego Stelmasiaka odpowiedzialność administracyjną ponosi każdy podmiot (przedsiębiorca, osoba fizyczna, jednostka organizacyjna nieposiadająca osobowości prawnej) prowadzący działalność uciążliwą dla środowiska, jeśli naruszył obowiązujące prawnie nakazy, zakazy, czy też ograniczenia w formie obowiązków administracyjnych, bądź ustalenia prawomocnej decyzji administracyjnej. Przy czym sprawca zanieczyszczenia środowiska ponosi odpowiedzialność niezależnie od wystąpienia przesłanki winy czy jej braku. Jedyną przesłanką pociągnięcia do odpowiedzialności administracyjnej jest tzw. obiektywnie ujęte bezprawie administracyjne ${ }^{24}$.

Podkreślić należy fakt, że w art. 1 ustawy o ochronie zwierząt wskazano, iż zwierzę jest to ,istota żyjąca, zdolna do odczuwania cierpienia”, przy czym nie jest rzeczą w rozumieniu k.c. Człowiek w stosunku do zwierząt powinien zatem wykazywać zachowania, które zwykle odnoszone są do istot żywych, zdolnych do pewnych odczuć (np. cierpienia), a nie przedmiotów (rzeczy). Takie podejście do zwierząt to jednak bardzo znacząca zmiana. Aczkolwiek zauważyć należy, że art. 2 tejże ustawy stanowi, iż: „W sprawach nieuregulowanych w ustawie do zwierząt stosuje się odpowiednio przepisy dotyczące rzeczy”.

Zdaniem Jana Białocerkiewicza nie do zaakceptowania na gruncie prawa pozytywnego jest dwoistość polegająca na tym, że dana jednostka jednocześnie nie jest rzeczą i nią jest. „Dereifikacja oznacza, że zwierzę staje się podmiotem w prawie publicznym i prywatnym $\mathrm{z}$ ograniczeniem dotyczącym sfery ekono-

23 A. Kwaśnicka, op. cit., s. 66-70.

24 J. Stelmasiak, op. cit., s. 155. 
micznej. Pozostaje tylko sprecyzowanie tej podmiotowości co do jej charakteru i zakresu"25. Przedmiotem regulacji ustawowej jest tutaj postępowanie ze zwierzętami kręgowymi, w tym zwierzętami kręgowymi wykorzystywanymi do celów naukowych lub edukacyjnych, ale tylko w zakresie nieuregulowanym w ustawie o ochronie zwierząt wykorzystywanych do celów naukowych lub edukacyjnych. Zaakcentować też należy, że właściwe organy administracji rządowej oraz organy samorządu terytorialnego mają obowiązek (art. 3 ustawy o ochronie zwierząt) współdziałania, w celu realizacji zadań nałożonych ustawowo, nie tylko z Inspekcją Weterynaryjną czy samorządem lekarsko-weterynaryjnym, ale także z wszelkimi instytucjami i organizacjami, których statutowym celem działania jest właśnie ochrona zwierząt ${ }^{26}$. Teresa Liszcz jest przekonana, że art. 1 ustawy o ochronie zwierząt jest początkiem przełomu w sytuacji zwierząt w polskim społeczeństwie, ale na skutki trzeba jeszcze trochę poczekać27. Ewa Łętowska z kolei sam fakt dereifikacji oceniła pozytywnie, przytaczając następujące argumenty:

— aprobata dla samych założeń ideowych etyki ekologicznej i wynikającego z niej krytycyzmu wobec reifikacji zwierzęcia, istoty żyjącej;

— przekonanie o wartości i potrzebie kultywowania, również w prawie, terminologii odzwierciedlającej aksjologię (chodzi o nienazywanie istoty żyjącej rzeczą);

- nieprzekonujący charakter krytyki dereifikacji wynikający z niedostrzeżenia jej istoty;

— brak przeszkód dogmatycznych w przyjęciu takiego rozwiązania ${ }^{28}$.

Warte zauważenia jest stanowisko Adama Habudy i Wojciecha Radeckiego, którzy podkreślają, że

przyjęcie przez prawodawcę założenia, iż zwierzęta nie są rzeczami, jest rezultatem odejścia od bezwzględnego antropocentryzmu, co przejawia się choćby w Światowej Deklaracji Praw Zwierzęcia przyjętej w Paryżu przez UNESCO w 1978 r. Owa Deklaracja nie ma charakteru normy prawa międzynarodowego, jest raczej normą moralną, co wszakże nie przeszkodziło wielu zasadom w niej zawartym stać się normami w niektórych porządkach prawnych ${ }^{29}$.

Zasadniczym środkiem prawnym, który służy ochronie zwierząt, zgodnie z zapisami ustawy o ochronie zwierząt, jest nadal akt administracyjny. I tak: jeżeli zwierzę traktowane jest w sposób niehumanitarny, czyli zachodzi znęcanie się nad nim, to, jak wyżej już zasygnalizowano, może być ono czasowo odebrane

25 J. Białocerkiewicz, Status prawny zwierząt. Prawa zwierząt czy prawna ochrona zwierząt, Torun 2005, s. 107.

26 J. Stelmasiak, op. cit., s. 155.

27 T. Liszcz, Zwierzęta w prawie stanowionym, „Więź” 1998, nr 7, s. 50.

28 E. Łętowska, Dwa cywilnoprawne aspekty praw zwierząt: dereifikacja i personifikacja, [w:] Studia z prawa prywatnego. Księga pamiatkowa ku czci profesor Biruty Lewaszkiewicz-Petrykowskiej, red. A. Szpunar, Łódź 1997, s. 85-86.

29 A. Habuda, W. Radecki, Przepisy karne wustawach wochronie zwierząt oraz o doświadczeniach na zwierzętach, „Prokuratura i Prawo” 2008, nr 5, s. 21. 
właścicielowi bądź opiekunowi. Następuje to w formie decyzji administracyjnej wydawanej w I instancji przez wójta (burmistrza, prezydenta miasta) po uzyskaniu informacji od Policji, straży gminnej, lekarza weterynarii lub upoważnionego przedstawiciela organizacji społecznej, której statutowym celem działania jest ochrona zwierząt. Decyzja taka podlega natychmiastowemu wykonaniu. Od decyzji tej przysługuje prawo wniesienia odwołania do samorządowego kolegium odwoławczego w ciągu 3 dni od dnia doręczenia decyzji. Z kolei samorządowe kolegium odwoławcze ma 7 dni na rozpoznanie tegoż odwołania. Jeśli wystąpi przypadek niecierpiący zwłoki, gdy dalsze pozostawanie danego zwierzęcia u dotychczasowego właściciela czy opiekuna zagraża jego życiu lub zdrowiu, to policjant, strażnik gminny lub upoważniony przedstawiciel organizacji społecznej, której statutowym celem działania jest ochrona zwierząt, odbiera dane zwierzę, przy czym niezwłocznie powiadamia o tym fakcie właściwego miejscowo wójta (burmistrza, prezydenta miasta), celem podjęcia decyzji w przedmiocie odebrania zwierzęcia dotychczasowemu właścicielowi lub opiekunowi. Jeśli sąd nie orzeknie przepadku zwierzęcia lub jeśli postępowanie w tej sprawie zostanie umorzone, to odebrane zwierzę podlega zwrotowi ${ }^{30}$. W opinii Mieczysława Goettela, z którą należy się zgodzić, analiza unormowań prawnych dotyczących czasowego odebrania zwierzęcia wskazuje, iż jest to instytucja niepozbawiona ułomności, co staje się źródłem licznych kontrowersji oraz utrudnia jej praktyczne stosowanie ${ }^{31}$.

Ustawa o ochronie zwierząt stanowi regulację prawną, która wprowadza pewne reguły ogólne, na jakich opierają się relacje człowiek-zwierzę, natomiast pozostałe akty prawne, należące do materii prawa administracyjnego, odnoszą się jedynie do określonych sfer relacji człowiek-zwierzę, przy czym zakresów tych sfer nie da się ustalić według jakichś jednolitych kryteriów. W pewnym sensie na pewno część spośród wymienionych aktów uzupełnia bądź konkretyzuje postanowienia ustawy o ochronie zwierząt.

Wspomnieć w tym miejscu trzeba ustawę o ochronie zwierząt wykorzystywanych do celów naukowych lub edukacyjnych. W przepisach tej ustawy silnie zaznaczona jest - podobnie jak w ustawie o ochronie zwierząt - idea humanitarnej ochrony zwierzą̧ ${ }^{32}$. Remigiusz Węgrzynowicz i Monika Romańska stawiają pytanie, czy możliwa jest zupełna eliminacja eksploatacji zwierząt w badaniach naukowych. Jest to problem dyskusji społecznej toczonej od wielu lat w kategoriach zarówno prawnych, jak i etycznych. Przeprowadzając jednak doświadczenia na zwierzętach, należy, zdaniem ww. autorów:

- przestrzegać zasad etycznych,

— postępować zgodnie z prawem,

30 Zob. J. Stelmasiak, op. cit., s. 155-156. Zob. też: M. Goettel, op. cit., s. 258-273, oraz idem, „,Czasowe odebranie” oraz ,przepadek” jako szczególne środki prawnej ochrony zwierząt, „Studia Prawnoustrojowe" 2011, nr 13, s. 146 n.

31 M. Goettel, Sytuacja zwierzęcia..., s. 273.

32 Ibidem, s. 238. 
— wykorzystywać postęp w metodach badawczych,

— działalność musi wynikać z faktycznych potrzeb społecznych,

— rozwijać metody alternatywne ${ }^{33}$.

Z kolei, żeby postulaty prawne i normy etyczne zostały spełnione, wymagane jest, jak twierdzą Węgrzynowicz i Romańska:

- przygotowanie kadry naukowej,

- wysoki poziom etyczny badaczy,

— unowocześnienie pracowni naukowych,

— pełne wykorzystanie informacji naukowych,

— unowocześnienie dydaktyki,

— działanie Komisji Etycznych ds. doświadczeń na zwierzętach ${ }^{34}$.

Ustawa o ochronie zwierząt wykorzystywanych do celów naukowych i edukacyjnych określa zasady i warunki ochrony zwierząt do tych celów wykorzystywanych. Formułuje ona:

1) zasady:

a) wykonywania procedur i przeprowadzania doświadczeń,

b) prowadzenia działalności przez hodowców, dostawców i użytkowników,

c) przeprowadzania kontroli hodowców, dostawców i użytkowników;

2) warunki utrzymywania zwierząt wykorzystywanych do celów naukowych lub edukacyjnych oraz sposób postępowania z tymi zwierzętami;

3) zadania i kompetencje komisji etycznych do spraw doświadczeń na zwierzętach ${ }^{35}$.

Organami właściwymi do udzielania i zmiany zgód na przeprowadzanie doświadczeń są Krajowa Komisja Etyczna ds. Doświadczeń na Zwierzętach i lokalne komisje etyczne ds. doświadczeń na zwierzętach ${ }^{36}$. Do zadań lokalnej komisji należy:

1) udzielanie zgody na:

a) przeprowadzanie doświadczenia,

b) zmianę doświadczenia;

2) cofanie udzielonej zgody na przeprowadzenie doświadczenia;

3) sprawdzanie doświadczenia według kryteriów, zwanych oceną retrospektywną, oraz przechowywanie wyników tej oceny (lokalna komisja dokonuje takiej oceny w przypadku doświadczeń: 1) w których są wykorzystywane zwierzęta z rzędu naczelnych; 2) obejmujących procedurę zakwalifikowaną do kategorii „dotkliwa");

4) przekazywanie, na wniosek powiatowego lekarza weterynarii przeprowadzającego kontrolę użytkownika w zakresie doświadczeń, informacji niezbędnych do prawidłowego przeprowadzenia tej kontroli;

${ }^{33}$ R. Węgrzynowicz, M. Romańska, Ochrona zwierząt w świetle prawa i norm etycznych, [w:] Prawna ochrona zwierząt, s. 89.

34 Ibidem.

35 Ustawa o ochronie zwierząt wykorzystywanych do celów naukowych lub edukacyjnych, art. 1 ust. 1.

36 Ibidem, art. 32 ust. 1. 
5) udostępnianie w Biuletynie Informacji Publicznej na stronie podmiotowej ministra właściwego do spraw nauki nietechnicznych streszczeń doświadczeńn ${ }^{37}$.

Doświadczenia przeprowadza się po uzyskaniu zgody komisji lokalnej, właściwej ze względu na lokalizację ośrodka, wydawanej na wniosek użytkownika. Lokalna komisja, po dokonaniu oceny doświadczenia, w terminie 40 dni roboczych od dnia otrzymania wniosku podejmuje uchwałę o:

1) udzieleniu zgody na przeprowadzenie doświadczenia;

2) odmowie udzielenia zgody na przeprowadzenie doświadczenia.

Zgoda taka jest udzielana na czas określony, nie dłuższy niż 5 lat ${ }^{38}$.

Kontrolę hodowców, dostawców i użytkowników w zakresie prowadzonej przez nich działalności objętej wpisem do rejestru przeprowadza powiatowy lekarz weterynarii właściwy ze względu na lokalizację ośrodka. Jeśli lekarz ten stwierdzi w toku kontroli, że procedura, w której są wykorzystywane zwierzęta, nie jest objęta doświadczeniem, na którego przeprowadzenie została udzielona zgoda, to nakazuje, w drodze decyzji administracyjnej, wstrzymanie przeprowadzenia takiego doświadczenia. Jeżeli użytkownik wykonuje procedury objęte doświadczeniem niezgodnie $\mathrm{z}$ warunkami określonymi w zgodzie na jego przeprowadzenie lub takiej zgody w ogóle nie uzyskał, wówczas powiatowy lekarz weterynarii:

1) wyznacza termin na usunięcie stwierdzonych nieprawidłowości;

2) nakazuje, w drodze decyzji administracyjnej, wstrzymanie wykonywania procedury albo przeprowadzania doświadczenia do czasu usunięcia stwierdzonych nieprawidłowości, jeżeli mogą one narażać zwierzęta na niepotrzebny ból, cierpienie i dystres.

Decyzje powiatowego lekarza weterynarii wydane po kontroli podlegają natychmiastowemu wykonaniu ${ }^{39}$. W ustawie o ochronie zwierząt wykorzystywanych do celów naukowych lub edukacyjnych przewidziano administracyjne kary pieniężne w wysokości od 1000 do 50000 zł nakładane na hodowców, dostawców lub użytkowników naruszających przepisy ustawy. Przy ustalaniu wysokości takiej kary uwzględnia się:

1) rodzaj i okoliczności naruszenia;

2) wpływ naruszenia na powstanie u zwierząt niepotrzebnego bólu, cierpienia, dystresu lub trwałego uszkodzenia organizmu;

3) okres trwania naruszenia;

4) dotychczasową działalność hodowcy, dostawcy i użytkownika.

Omawiane kary pieniężne wymierza, w drodze decyzji administracyjnej, minister właściwy do spraw nauki ${ }^{40}$.

Szczególne regulacje prawne z zakresu ochrony zdrowia i dobrostanu zwierząt są z kolei zawarte zwłaszcza w ustawach:

37 Ibidem, art. 36 ust. 1 , art. 53 ust. 1.

38 Ibidem, art. 42, art. 43 ust. 1, art. 48 ust. 1, 2, art. 49 ust. 3.

39 Ibidem, art. 54 ust. 1, art. 57 ust. 1, 2, 3.

40 Ibidem, art. 69 ust. 1, art. 70 ust. 1, 2, art. 71 ust. 1. 
1) o ochronie zdrowia zwierząt oraz o zwalczaniu chorób zakaźnych zwierząt, która określa wymagania weterynaryjne w zakresie działalności gospodarczej, działalności wytwórczej w rolnictwie lub działalności zawodowej, związanej ogólnie ze zwierzętami (np. zarobkowy transport zwierząt, obrót zwierzętami czy prowadzenie schronisk dla zwierząt), oraz zasady dotyczące m.in. zwalczania chorób zakaźnych zwierząt, w tym odzwierzęcych;

2) o zakładach leczniczych dla zwierząt, która reguluje system organizacyjny placówek świadczących usługi weterynaryjne, a więc czynności mające na celu zachowanie, ratowanie lub poprawę zdrowia zwierząt i ich produkcyjności oraz zasady świadczenia ww. usług;

3) o Inspekcji Weterynaryjnej, która określa organizację i zadania podmiotów wchodzących w skład systemu Inspekcji Weterynaryjnej.

Ważne miejsce zajmuje też ustawa o zapobieganiu szkodom w środowisku i ich naprawie, korespondująca z ustawą - Prawo ochrony środowiska. Ustawa o zapobieganiu szkodom $\mathrm{w}$ środowisku i ich naprawie formułuje zasady stosowania instrumentów o charakterze administracyjnoprawnym, zwłaszcza w drodze nakładania na pewne podmioty obowiązków w zakresie podejmowania działań zapobiegawczych i naprawczych oraz ich egzekwowania, w sytuacji bezpośredniego zagrożenia szkodą w środowisku lub jej wystąpienia. Szkoda w środowisku polega na negatywnych zmianach stanu elementów przyrodniczych, m.in. w chronionych gatunkach zwierząt lub chronionych siedliskach przyrodniczych.

W przepisach ustawy o ochronie przyrody natomiast najpełniej realizowana jest ochrona zwierząt wolno żyjących. Do zasobów, tworów i składników przyrody poddanych ochronie zalicza ta ustawa wszystkie zwierzęta dziko żyjące. Ochronę tę zapewnia w szczególności poddanie specjalnemu reżimowi wybranych gatunków zwierząt (tzw. ochrona gatunkowa), ale też ustanowienie chronionych obszarów oraz obiektów. Ochrona gatunkowa odnosi się do zwierząt rzadkich, endemicznych, podatnych na zagrożenia i zagrożonych wyginięciem oraz objętych ochroną na podstawie umów międzynarodowych, a także ich siedlisk i ostoi, przy czym dla ochrony tych miejsc mogą być wyznaczane strefy ochrony. W ramach ochrony gatunkowej zwierzęta mogą być poddane ochronie ścisłej, czyli wykluczającej całkowicie i trwale ingerencję człowieka, bądź ochronie częściowej, tj. dopuszczającej możliwość redukcji liczebności populacji oraz pozyskiwania osobników ${ }^{41}$. W ogólnym ujęciu celami ochrony gatunkowej są zabezpieczenie gatunków dziko występujących, a zwłaszcza gatunków rzadkich i zagrożonych wyginięciem, jak również zachowanie gatunkowej i genetycznej różnorodności. Dąży zatem ona do zagwarantowania trwałości istnienia wszystkich gatunków ${ }^{42}$. Gatunki rzadko występujące to takie, które są zagrożone w swym bycie i liczebności, oraz reliktowe

${ }^{41}$ M. Goettel, Sytuacja zwierzęcia..., s. 239-242.

42 E. Mazur, Środowisko przyrodnicze. Zagrożenia, ochrona i ksztaltowanie, Szczecin 2004, s. $147-148$. 
gatunki będące pozostałością danej fauny ograniczającej się do niewielkich populacji. Gatunki endemiczne z kolei to takie, które odgrywają znaczącą rolę w historii gatunku oraz zmian jego środowiska i występują na małych powierzchniach. Zagrożone wyginięciem i podatne na zagrożenie wyginięciem są gatunki nadmiernie pozyskiwane i zabijane ${ }^{43}$. Ochrona konserwatorska może się okazać jednak mało skuteczna i niewystarczająca, stąd powinna być ona uzupełniona prawną ochroną całych ekosystemów, w których występują określone gatunki, oraz ochroną ex-situ (poza środowiskiem naturalnym) realizowaną np. w ogrodach zoologicznych ${ }^{44}$.

Szczególnej dziedziny postępowania człowieka wobec zwierząt wolno żyjących dotyczy ustawa - Prawo łowieckie, która reguluje zasady gospodarowania zasobami zwierząt łownych, czyli działalność nazywaną łowiectwem, akcentując jednocześnie, iż działalność ta, jako element ochrony środowiska przyrodniczego, oznacza także ochronę zwierząt łownych. Istotną materię tej ustawy stanowi też reglamentacja wykonywania polowania jako jednego z elementów gospodarki łowieckiej. Postanowienia tej ustawy określają zwłaszcza uprawnienia do wykonywania polowania, w szczególności kwalifikacje, jakie muszą posiadać osoby polujące, ogólne warunki i zasady wykonywania polowania, a także przesłanki i tryb wykonania odłowu lub odstrzału redukcyjnego oraz odstrzału zastępczego zwierzyny. Czas nieobjęty okresem polowań jest tzw. okresem ochronnym ${ }^{45}$.

Osobne regulacje zapewniają ochronę zwierzętom żyjącym w środowisku wodnym. Przede wszystkim wskazać tu należy ustawę o rybactwie śródlądowym regulującą w szczególności zasady i warunki ochrony, chowu, hodowli oraz połowu ryb i innych organizmów wodnych w powierzchniowych wodach śródlądowych. Część z tych organizmów należy do kategorii zwierząt wolno żyjących, a część ma taki sam charakter jak zwierzęta gospodarskie. Podobne rozwiązania ochronne zawiera też ustawa o rybołówstwie, która odnosi się zwłaszcza do zasad dokonywania połowów organizmów morskich, w tym ochrony żywych zasobów morza ${ }^{46}$.

Powyższe unormowania są jedynie przykładami i nie wyczerpują całości regulacji prawa administracyjnego dotyczących problematyki zwierząt. Jak już podkreślono, poza aktami prawnymi, odnoszącymi się w całości lub zasadniczej części do kwestii ochrony zwierząt, występują także incydentalne rozwiązania dotyczące interesującej nas problematyki, a umieszczone w aktach prawnych poświęconych zupełnie innej materii.

Inne jeszcze zagadnienie wiąże się z wydawaniem zezwolenia na utrzymywanie lub prowadzenie hodowli psów rasy uznanej za agresywną. Decyzję w tej sprawie wydaje wójt (burmistrz, prezydent miasta) właściwy ze względu na pla-

43 Ł. Smaga, Ochrona humanitarna zwierząt, Białystok 2010, s. 98-99.

44 M. Nowicki, Strategia ekorozwoju Polski, Warszawa 1993, s. 81.

45 W. Radecki, Prawo łowieckie. Komentarz, Warszawa 2014, s. 265. Zob. też szeroko na ten temat: R. Stec, Uprawianie łowiectwa i prowadzenie gospodarki łowieckiej. Uwarunkowania administracyjnoprawne, cywilnoprawne i organizacyjne, Warszawa 2012.

46 M. Goettel, Sytuacja zwierzęcia ..., s. 245. 
nowane miejsce prowadzenia hodowli lub utrzymywania psa na wniosek osoby, która zamierza prowadzić taką hodowlę bądź utrzymywać takiego psa. Wójt (burmistrz, prezydent miasta) nie wydaje zezwolenia, a wydane cofa, jeśli pies będzie lub jest utrzymywany w warunkach i w sposób, które stanowią zagrożenie dla ludzi lub zwierząt. Rozstrzygnięcia w omawianej sprawie podejmowane są w formie decyzji administracyjnej ${ }^{47}$.

Jeśli zaś chodzi o hodowlę zwierząt gospodarskich, to ustawodawca zakazuje podawania zwierzętom w karmie hormonów wzrostu; zakazuje też tuczu gęsi i kaczek na stłuszczone wątroby oraz utrzymywania cieląt powyżej 8. tygodnia życia w pojedynczych boksach i na uwięzi, z wyjątkiem pory karmienia, a w czasie jej trwania nie dłużej niż godzinę. Przedmiotowe zakazy są jednakże sankcjonowane odpowiedzialnością karną, a nie administracyjną. Ponadto wprowadzenie dotychczas niestosowanej na terytorium RP technologii wymaga uzyskania zezwolenia wydawanego przez marszałka województwa po stwierdzeniu, że technologia spełnia wymagania ustawowe w tym zakresie ${ }^{48}$. Również zakazy wprowadzone w art. 14 ustawy o ochronie zwierząt, dotyczące sposobu i warunków używania zwierząt do pracy pod kątem ochrony ich zdrowia i życia, objęte są sankcją odpowiedzialności karnej, a nie administracyjnej. Wykorzystywanie z kolei zwierząt do celów rozrywkowych, widowiskowych, filmowych, sportowych i specjalnych prawodawca unormował bezpośrednio w ustawie o ochronie zwierząt poprzez wprowadzenie szeregu zakazów sankcjonowanych odpowiedzialnością karną. Wśród tych zakazów są np. zakaz zmuszania zwierząt do wykonywania czynności, które powodują ból lub sprzeczne są z ich naturą, zakaz działalności menażerii objazdowych czy zakaz wykorzystywania zwierząt w widowiskach i sportach noszących znamiona okrucieństwa ${ }^{49}$.

Kolejna kwestia to pozyskiwanie zwierząt wolno żyjących (dzikich) w celu preparowania ich zwłok. Pozyskiwanie takie wymaga zezwolenia marszałka województwa właściwego ze względu na miejsce wykonywania eksponatów. Marszałek wydaje takie zezwolenie tylko w przypadku, gdy zwłoki zwierząt będą preparowane wyłącznie w celu naukowym, dydaktycznym lub edukacyjnym. W takim zezwoleniu ustala warunki i sposób pozyskiwania zwierząt dla wspomnianych celów, po uzyskaniu opinii starosty właściwego ze względu na miejsce pozyskiwania zwierząt. Zezwolenia nie wydaje się, a wydane cofa, jeśli zachodzi uzasadniona potrzeba ochrony zasobów genetycznych lub przemawiają za tym względy sanitarne. Podobnie, zgody marszałka województwa właściwego ze względu na miejsce tworzenia takiej kolekcji wymaga pozyskiwanie zwierząt wolno żyjących (dzikich) celem tworzenia kolekcji spreparowanych zwłok tych zwierzą ${ }^{50}$.

\footnotetext{
47 Ustawa o ochronie zwierząt, art. 10 ust. 1, 2, 2a, 2c.

48 Ibidem, art. 12 ust. 4, 4a, art. 13.

49 J. Stelmasiak, op. cit., s. 157.

50 Ustawa o ochronie zwierząt, art. 22 ust. 1, 2, 3, 5, art. 22a.
} 
Następny przypadek związany ze stosowaniem formy działania administracji publicznej dotyczy sytuacji, gdy konieczne jest uśmiercenie zwierząt. Jeśli Generalny Dyrektor Ochrony Środowiska lub regionalny dyrektor ochrony środowiska wydał zezwolenie na zabicie zwierząt objętych ochroną gatunkową, mogą one być uśmiercone przy użyciu broni myśliwskiej przez osoby uprawnione do podsiadania tejże broni. Generalnie wymagana jest na to zgoda właściciela zwierzęcia, ale zwierzę może być uśmiercone bez zgody właściciela na podstawie orzeczenia lekarza weterynarii. Ustalenie właściciela i uzyskanie jego zgody nie dotyczy zwierząt chorych na choroby zwalczane z urzędu. Natomiast gdy bezzwłoczne uśmiercenie zwierzęcia jest niezbędne do realizacji zadań związanych z ochroną przyrody na obszarze parku narodowego, to potrzebę uśmiercenia zwierzęcia stanowiącego zagrożenie stwierdza w drodze decyzji administracyjnej dyrektor parku narodowego, na którego obszarze znajduje się owo zwierzę 51 . Dodatkowe samodzielne przesłanki uzasadniające zabicie zwierząt wprowadza art. 33a ustawy o ochronie zwierząt, stanowiąc, że w sytuacji gdy zwierzęta stanowią nadzwyczajne zagrożenie dla życia, zdrowia lub gospodarki człowieka, w tym gospodarki łowieckiej, dopuszcza się podjęcie działań, których celem jest ograniczenie populacji tych zwierząt. Michał Gabriel-Węglowski utrzymuje, że choć przedmiotowa ustawa nie stwierdza tego wprost, jedną $\mathrm{z}$ form ograniczania populacji może być w tym wypadku fizyczna eliminacja danych zwierząt (np. odstrzał wilków) ${ }^{52}$. Podstawą prawną jest tutaj uchwała sejmiku województwa, po zasięgnięciu opinii regionalnej rady ochrony przyrody, organizacji społecznej, której statutowym celem działania jest ochrona zwierząt, oraz Polskiego Związku Łowieckiego ${ }^{53}$.

Pozostaje jeszcze kwestia transportu zwierząt. W tej kwestii powiatowy lekarz weterynarii:

— wydaje, w drodze decyzji administracyjnej, zezwolenie na prowadzenie działalności w zakresie przewozu zwierząt ${ }^{54}$;

— zatwierdza, w drodze decyzji administracyjnej, środki transportu przeznaczone do długotrwałego, a więc przekraczającego 8 godzin, przewozu zwierząt ${ }^{55}$; — kontroluje oraz dokonuje wpisów w dzienniku podróży, w szczególności weryfikuje proponowaną przez przewoźnika trasę przewozu zwierząt — przed

51 Ibidem, art. 33 ust. 1b, 2, 3a.

52 M. Gabriel-Węglowski, Przestęstwa przeciwko humanitarnej ochronie zwierząt, Toruń 2005, s. 91.

53 Ustawa o ochronie zwierząt, art. 33a ust. 2.

54 Art. 10 Rozporządzenia Rady (WE) nr 1/2005 z dnia 22 grudnia 2004 r. w sprawie ochrony zwierząt podczas transportu i związanych z tym działań oraz zmieniającego dyrektywy 64/432/EWG i 93/119/WE oraz rozporządzenie (WE) nr 1255/97 (Dz. Urz. UE L 3 z 5 stycznia 2005 r.) w powiązaniu z art. 24a ustawy o ochronie zwierząt.

55 Art. 11 Rozporządzenia Rady (WE) nr 1/2005 z dnia 22 grudnia 2004 r. w sprawie ochrony zwierząt podczas transportu i związanych z tym działań oraz zmieniającego dyrektywy 64/432/EWG i 93/119/WE oraz rozporządzenie (WE) nr 1255/97 (Dz. Urz. UE L 3 z 5 stycznia 2005 r.) w powiązaniu $\mathrm{z}$ art. 24a ustawy o ochronie zwierząt. 
rozpoczęciem transportu, a następnie w ciągu miesiąca po zakończeniu transportu otrzymuje od przewoźnika kopię dziennika podróży, co pozwala mu na stwierdzenie, czy przewoźnik transportował zwierzęta zgodnie z zaakceptowaną trasą̨

— w punktach kontroli potwierdza w dzienniku podróży spełnienie wymagań dotyczących dobrostanu zwierząt oraz fakt, że zwierzęta nadają się do dalszego transportu ${ }^{57}$;

- kontroluje spełnianie warunków transportu oraz stanu zwierząt w transporcie w miejscu załadunku, miejscu docelowym, w trakcie transportu drogowego oraz w punktach kontroli granicznej i w punktach wyjścia ${ }^{58}$.

\section{PODSUMOWANIE}

Po przeprowadzeniu powyższych rozważań można sformułować wniosek, że dominującą prawną formą działania organów administracji publicznej w zakresie ochrony zwierząt jest akt administracyjny ${ }^{59} \mathrm{w}$ postaci decyzji administracyjnej. Jeśli zaś chodzi o inne formy działania administracji stosowane w zakresie ochrony zwierząt, to należy wyróżnić zwłaszcza formę aktów normatywnych wydawanych na podstawie upoważnień zawartych w ustawie przez rząd lub właściwego ministra, ale też przez organy samorządu terytorialnego $\mathrm{w}$ formie aktów prawa miejscowego ${ }^{60}$. I tak: odławianie bezdomnych zwierząt odbywa się tylko na podstawie uchwały rady gminy, która wypełniając swój obowiązek, określa (też w drodze uchwały), do 31 marca każdego roku, program opieki nad zwierzętami bezdomnymi oraz zapobiegania bezdomności zwierząt. Projekt tego programu przygotowuje wójt (burmistrz, prezydent miasta) i przekazuje go najpóźniej do 1 lutego do zaopiniowania właściwemu powiatowemu lekarzowi weterynarii, organizacjom społecznym, których statutowym celem działania jest ochrona zwie-

56 Art. 14 Rozporządzenia Rady (WE) nr 1/2005 z dnia 22 grudnia 2004 r. w sprawie ochrony zwierząt podczas transportu i związanych z tym działań oraz zmieniającego dyrektywy 64/432/EWG i 93/119/WE oraz rozporządzenie (WE) nr 1255/97 (Dz. Urz. UE L 3 z 5 stycznia 2005 r.) w powiązaniu z art. 24a ustawy o ochronie zwierząt.

57 Art. 15 Rozporządzenia Rady (WE) nr 1/2005 z dnia 22 grudnia 2004 r. w sprawie ochrony zwierząt podczas transportu i związanych z tym działań oraz zmieniającego dyrektywy 64/432/EWG i 93/119/WE oraz rozporządzenie (WE) nr 1255/97 (Dz. Urz. UE L 3 z 5 stycznia 2005 r.) w powiązaniu z art. 24a ustawy o ochronie zwierząt.

58 Art. 24 Rozporządzenia Rady (WE) nr 1/2005 z dnia 22 grudnia 2004 r. w sprawie ochrony zwierząt podczas transportu i związanych z tym działań oraz zmieniającego dyrektywy 64/432/EWG i 93/119/WE oraz rozporządzenie (WE) nr 1255/97 (Dz. Urz. UE L 3 z 5 stycznia 2005 r.) w powiązaniu z art. 24a ustawy o ochronie zwierząt.

59 „Akt administracyjny jest konstrukcją prawną obejmującą taką postać działania organu administracji publicznej, przy pomocy której organ ten w oparciu o wyraźne przepisy ustawy i dokonanie ustalenia stanu faktycznego, władczo i jednostronnie rozstrzyga o prawach i obowiązkach konkretnego adresata" - zob. A. Błaś, Akty administracyjne, [w:] Prawo administracyjne, red. J. Boć, Wrocław 2004, s. 322.

60 J. Stelmasiak, op. cit., s. 160, 162.

Przegląd Prawa i Administracji 108, 2017

(C) for this edition by CNS 
rząt na obszarze gminy, oraz dzierżawcom lub zarządcom obwodów łowieckich, działających w gminie. Wymienione podmioty w ciągu 21 dni od dnia otrzymania projektu programu wydają opinie o projekcie, przy czym niewydanie takiej opinii w terminie uznaje się za akceptację przedłożonego do zaopiniowania projektu programu $^{61}$. Z kolei zarząd województwa ma obowiązek ustawowy przygotować i wykonać program upowszechniania znajomości przepisów ustawy o ochronie zwierząt wśród rolników przez wojewódzkie ośrodki doradztwa rolniczego ${ }^{62}$. Zdaniem Stelmasiaka jest to przykład działalności społeczno-organizatorskiej, która nie jest sankcjonowana władztwem administracyjnym ${ }^{63}$.

Warto w tym miejscu dodać, że w listopadzie 2016 r. posłowie przegłosowali dwie ważne zmiany do ustawy o ochronie zwierząt. Pierwsza kończy spór o legalność finansowania przez gminy sterylizacji psów i kotów posiadających właścicieli. Druga otwiera katalog działań samorządów na rzecz zapobiegania bezdomności zwierząt. Wprowadzenie obu poprawek postulowała Najwyższa Izba Kontroli. Podkreślić należy, że NIK od wielu miesięcy wskazywała na potrzebę wpisania do ustawy o ochronie zwierząt możliwości całkowitego lub częściowego finansowania przez gminy kastracji/sterylizacji psów i kotów posiadających właścicieli. Do niedawna samorządy podejmujące takie akcje robiły to bez jednoznacznej delegacji prawnej. W rezultacie zdarzało się, że wojewodowie wydawali uchylenia nadzorcze blokujące dopłaty do kastracji/sterylizacji. Izba wielokrotnie wskazywała, że sterylizacja jest jednym z najistotniejszych sposobów zapobiegania bezdomności zwierząt. Eksperci z Rady ds. Wspierania Działań na Rzecz Ochrony Zwierząt, działającej przy prezesie NIK, podają liczne przykłady. I tak np. w gminie Myszków w wyniku wprowadzenia programu sterylizacji zwierząt właścicielskich w ciągu 5 lat liczba bezdomnych psów spadła z 270 do 100. Koszty opieki nad bezdomnymi zwierzętami zmniejszyły się odpowiednio z 405 tys. do 150 tys. zł.

Druga z przyjętych do ustawy o ochronie zwierząt zmian dotyczy katalogu zawartego w art. 11. Do tej pory pozostawał on katalogiem zamkniętym, co wiązało wielu samorządom ręce w kwestii zapobiegania bezdomności zwierząt. Obecnie każda gmina może w swojej uchwale zawrzeć autorskie projekty pomocy bezdomnym zwierzętom ${ }^{64}$.

${ }^{61}$ Ustawa o ochronie zwierząt, art. 11 ust. 3, art. 11a ust. 1, 6, 7, 8 .

62 Ibidem, art. 8 ust. 3.

63 J. Stelmasiak, op. cit., s. 163.

${ }^{64}$ Sejm przychylit się do wniosku NIK, https://www.nik.gov.pl/aktualnosci/sejm-przychyli1-sie-do-wniosku-nik.html (dostęp: 5 stycznia 2017). Zob. na temat zapobiegania bezdomności zwierząt: A. Golenia, M. Marek, Zadania własne gminy w zakresie praw zwierząt, [w:] Urzędnik jako strażnik realizacji ustawowych obowiązków wobec zwierzą, red. T. Pietrzykowski et al., Katowice 2016, oraz K. Brończyk, A. Brzostek, Program opieki nad bezdomnymi zwierzętami oraz zapobiegania bezdomności zwierząt, [w:] Urzędnik jako strażnik. Zob. także: T. Pietrzykowski, Opinia prawna w przedmiocie dopuszczalności kastracji (sterylizacji) kotów wolno żyjących i jego finansowania $w$ ramach programów, o których mowa $w$ art. 11a ust. 2 ustawy o ochronie zwierząt, [w:] Urzędnik jako strażik. 


\title{
BASIC LEGAL FORMS OF ACTION \\ OF THE PUBLIC ADMINISTRATION \\ FOR THE PROTECTION OF ANIMALS
}

\begin{abstract}
Summary
In the protection of animals an administrative act (in the form of the administrative decision) is a dominating legal form of action of public administration. Acts of the local law play an important role. For example, catching homeless animals takes place only based on the resolution of the commune council. Rarely are used other legal forms of action of the public administration, like material-technical activity, social-organizational activity or civil law agreements.
\end{abstract}

